\title{
Amygdaloid-striatal substrates underlying odor hedonics and odor-guided behaviors
}

\section{Colleen A. Payton and Daniel W. Wesson*}

Department of Neurosciences, Case Western Reserve University School of Medicine, Cleveland, OH, USA

*Correspondence: dww53@case.edu

\section{A commentary on}

Amygdaloid projections to the ventral striatum in mice: direct and indirect chemosensory inputs to the brain reward system by Novejarque, A., Gutiérrez-Castellanos, N., Lanuza, L., and Martínez-García, F. (2011). Front. Neuroanat. 5:54. doi: 10.3389/ fnana.2011.00054

Imagine taking a long sniff of your favorite dinner plate, and the strong sense of pleasure felt as you anticipate eating and eventually filing your hunger. Now, imagine the transient perception of sour milk from the carton and the rapid disgust this evoked. Olfactory system-mediated perception of odors has an astounding capacity to evoke emotional and behavioral responses (KirkSmith et al., 1983; Herz and Cupchick, 1995). This phenomenon is often attributed to the direct connections between primary olfactory structures (the main and accessory olfactory bulbs) and the amygdala. While the amygdala is indeed crucial for emotional responses (LeDoux, 2000), other structures, including those within the ventral striatum, likely perform similar functions in linking olfactory sensory input with appropriate behavioral responses (Wesson and Wilson, 2011). Thus, an understanding of the striatal-amygdala connectivity is paramount in elucidating the neural substrates for odor-evoked cognitive functions and behavioral responses.

Addressing this need, Novejarque et al. (2011) recently provided a masterfully detailed analysis of the amygdaloid nuclei projections to the ventral striato-pallidum. The authors employed anterograde and retrograde tract-tracing experiments in mice to examine amygdala connectivity with the olfactory tubercle, the nucleus accumbens, and the islands of Calleja. The authors demonstrated "direct" projections to the ventral striato-pallidum from the chemosensory cortical amygdala and "indirect" projections from the associative amygdala nuclei. Novejarque et al. (2011) hypothesize that the direct projections may be stimulated through an unconditioned response to odors, possibly pheromones, whereas the indirect projections would likely be stimulated through a learned response to associated stimuli. These projections interconnect with the nucleus accumbens, olfactory tubercle, and islands of Calleja in a manner possibly important for olfactory perception and odor-guided behaviors. Several notable findings stand out as promising in understanding the neuroanatomical basis for odor hedonics.

While amygdala innervation of the nucleus accumbens' core and shell regions has received considerable attention (e.g., Everitt et al., 1999), none were performed with such detail in mice as that performed by Novejarque et al. (2011). The amygdaloidstriatal projections likely subserve the expression of reward-related behaviors toward secondary reinforcers (Cador et al., 1989). In addition, these indirect projections may underlie learning-related modulation of odor hedonics as Novejarque et al. (2011) hypothesize. Thus, this information pathway is likely critical to the majority of our odor-based olfactory decisions and behaviors, which are arguably based upon learning more-so than innate preferences, or aversions. Perhaps correlating with the complexity and diversity of these learned behaviors, the authors report that the fiber pathways between the amygdala and ventral striatum (the stria terminalis, ansa peduncularis, and longitudinal association bundle) vary in density and destination depending upon their origin. These fiber pathways are likely to promote the regulation of social and sexual behaviors through hedonic functions as has been suggested from work in humans (Fox et al., 2010; Somerville et al., 2011).

Similar to that reported over previous years (Fallon et al., 1983; Ubeda-Bañona et al., 2007; Usunoff et al., 2009), the authors observed the dense innervation of the olfac- tory tubercle by the amygdala. The olfactory tubercle is a striatal structure with a cortical-like organization which displays odor-evoked activity and may be critical for olfactory perception (Wesson and Wilson, 2011). The anatomical findings by Novejarque et al. (2011) along with those of previous groups (Usunoff et al., 2009) suggest the involvement of the olfactory tubercle (and perhaps the tubercle's strong connections with the basal ganglia) in the emotional regulation of olfactory perception and the strong hedonic responses evoked by odors (e.g., Herz and Cupchick, 1995). Despite this, without data showing the role of the olfactory tubercle to olfactory processing, little can be inferred regarding the amygdala innervation of the olfactory tubercle.

Another major contribution of the present study was the finding that all cortical amygdaloid nuclei (excluding the piriform cortex) innervate the major island of Calleja. This was especially the case for the posteromedial cortical amygdaloid nucleus. The islands of Calleja are dense granule cell clusters residing mostly within layers II and III of the olfactory tubercle in rodents and largely in the nucleus accumbens in humans. However, the function of the islands of Calleja is unknown. Thus while this finding by Novejarque et al. (2011) is difficult to interpret in terms of functional consequences, it is almost undoubted that the amygdala's dense innervation of the major island of Calleja will be found important to the emotional modulation of odor perception (given their positioning within the olfactory tubercle) and to the regulation of sociosexual behaviors.

There are ample future directions to link these anatomical findings by Novejarque et al. (2011) to functional significance. First, and most recently discussed, would elimination or inactivation of the major island of Calleja abolish associative changes in odor hedonics? This of course is based upon the 
assumption that the islands of Calleja do in fact play a role in odor processing and/ or reward processes. Related, are particular amygdala outputs to these structures (the nucleus accumbens, olfactory tubercle, or islands of Calleja) more strongly involved in relaying hedonic information? Finally, given the known interconnections between the olfactory tubercle and nucleus accumbens (Zahm and Heimer, 1993), are the distinct inputs to each of these structures from the amygdala simply redundant, or do they each provide unique information regarding emotionally relevant processes? Answers to these and other questions will help us along our way to understanding the neural basis of odor hedonics and ultimately behaviors driven in large part by odor hedonics.

\section{REFERENCES}

Cador, M., Robbins, T. W., and Everitt, B. J. (1989). Involvement of the amygdala in stimulus-reward associations: interaction with the ventral striatum. Neuroscience 30, 77-86.

Everitt, B. J., Parkinson, J. A., Olmstead, M. C., Arroyo, M., Robledo, P., and Robbins, T.W. (1999). Associative processes in addiction and reward. The role of amyg- dala-ventral striatal subsystems. Ann. N. Y. Acad. Sci. 877, 412-438.

Fallon, J. H., Loughlin, S. E., and Ribak, C. E. (1983). The islands of Calleja complex of rat basal forebrain. III. Histochemical evidence for a striatopallidal system. J. Comp. Neurol. 218, 91-120.

Fox, A. S., Shelton, S. E., Oakes, T. R., Converse, A. K. Davidson, R. J., and Kalin, N.H. (2010). Orbitofrontal cortex lesions alter anxiety-related activity in the primate bed nucleus of stria terminalis. J. Neurosci. 30, 7023-7027.

Herz, R. S., and Cupchick, G. C. (1995). The emotional distinctiveness of odor-evoked memories. Chem. Senses 20, 517-528.

Kirk-Smith, M. D., van Toller, C., and Dodd, G.H. (1983). Unconscious odour conditioning in human subjects. Biol. Psychol. 17, 221-231.

LeDoux, J. E. (2000). Emotion circuits in the brain. Annu. Rev. Neurosci. 23, 155-184.

Novejarque, A., Gutierrez-Castellanos, N., Lanuza, E., and Martinez-Garcia, F. (2011). Amygdaloid projections to the ventral striatum in mice: direct and indirect chemosensory inputs to the brain reward system. Front. Neuroanat. 5:54. doi: 10.3389/fnana.2011.00054

Somerville, L. H., Whalen, P. J., and Kelley, W. M. (2011) Human bed nucleus of the stria terminalis indexes hypervigilant threat monitoring. Biol. Psychiatry 68, 416-424.

Ubeda-Bañona, I., Novejarque, A., Mohedano-Moriano, A., Pro-Sistiaga, P., de la Rosa-Prieto, C., Insausti, R., Martinez-Garcia, F., Lanuza, E., and Martinez-
Marcos, A. (2007). Projections from the posterolateral olfactory amygdala to the ventral striatum: neural basis for reinforcing properties of chemical stimuli. BMC Neurosci. 8, 103. doi: 10.1186/1471-2202-8-103

Usunoff, K. G., Schmitt, O., Itzev, D. E., Haas, S. J. P., Lazarov, N. E., Rolfs, A., and Wree, A. (2009). Efferent projections of the anterior and posterodorsal regions of the medial nucleus of the amygdala in the mouse. Cells Tissues Organs 190, 256-285.

Wesson, D. W., and Wilson, D. A. (2011). Sniffing out the contributions of the olfactory tubercle to the sense of smell: hedonics, sensory integration, and more? Neurosci. Biobehav. Rev. 35, 655-668.

Zahm, D. S., and Heimer, L. (1993). Specificity in the efferent projections of the nucleus accumbens in the rat: comparison of the rostral pole projection patterns with those of the core and shell. J. Comp. Neurol. 327, 220-232.

Received: 15 August 2011; accepted: 07 September 2011; published online: 26 September 2011.

Citation: Payton CA and Wesson DW (2011) Amygdaloidstriatal substrates underlying odor hedonics and odorguided behaviors. Front. Neuroanat. 5:61. doi: 10.3389/ fnana.2011.00061

Copyright (C) 2011 Payton and Wesson. This is an openaccess article subject to a non-exclusive license between the authors and Frontiers Media SA, which permits use, distribution and reproduction in other forums, provided the original authors and source are credited and other Frontiers conditions are complied with. 